Vidya Samhita : Jurnal Pelelitian Agama

Volume 7, Nomor 1, 2021. pp $37-42$

p-issn : 2460 - 3376, e-issn : $2460-4445$

https://www.ejournal.ihdn.ac.id/index.php/vs/indexa

\title{
“TANTANGAN DAN STRATEGI PEMBELAJARAN AGAMA HINDU PADA KELAS BERBASIS DARING DI MASA PANDEMI COVID-19"
}

\author{
Oleh \\ Ni Wayan Budiasih \\ Dosen Pendidikan Agama Hindu
}

\begin{abstract}
The Covid-19 pandemic has changed the order of life, one of which is the educational structure shown by the efforts of the Ministry of Education and Culture to launch a "learning from home" program as an alternative to learning in the midst of the Corona-19 virus pandemic Seeing this condition, the government is moving fast and trying to disseminate distance learning and is being responded positively by schools by conducting training activities in developing teacher competencies in optimizing online learning or online learning as a distance learning solution using computer devices or gadgets where teachers and students communicate interactively by utilizing communication and information media.
\end{abstract}

Keyword: The Covid-19 Pandemic, Online Learning, Communication and Information

\begin{abstract}
Abstrak
Pandemi Covid-19 banyak merubah tatanan kehidupan, salah satunya tatanan pendidikan itu ditunjukkan dengan upaya Kemendikbud meluncurkan program "belajar dari rumah" sebagai alternative belajar di tengah pandemic virus Corona-19). Melihat kondisi ini, pemerintah bergerak cepat dan berusaha mensosialisasikan pembelajaran jarak jauh dan direspon positif oleh sekolah-sekolah dengan melakukan kegiatan pelatihan dalam mengembangkan kompetensi guru dalam mengoptimalkan pembelajaran daring atau online learning sebagai solusi pembelajaran jarak jauh dengan menggunakan perangkat komputer atau gadget dimana guru dan siswa berkomunikasi secara interaktif dengan memanfaatkan media komunikasi dan informasi.
\end{abstract}

Kata Kunci: Pandemi Covid-19, Pembelajaran Daring, Komunikasi dan Informasi 


\section{PENDAHULUAN}

Pandemi Covid-19 banyak merubah tatanan kehidupan, salah satunya tatanan pendidikan, itu ditunjukkan dengan upaya Kemendikbud meluncurkan program "belajar dari rumah" sebagai alternative belajar di tengah pandemic virus Corona-19), sejak 16 Maret 2020 Pemerintah memutuskan agar siswa-siswinya belajar dari rumah dengan harapan dalam kondisi darurat seperti sekarang ini peserta didik terus mendapatkan haknya dalam mendapatkan ilmu pengetahuan secara formal.

Tidak bisa dibantah, banyak guru pendidikan agama Hindu belum mengenal apa itu pembelajaran jarak jauh dan bagaimana melakukannya, demikian pula dengan siswa masih belum familiar dengan pembelajaran jarak jauh. Melihat kondisi ini, pemerintah bergerak cepat dan berusaha mensosialisasikan pembelajaran jarak jauh dan direspon positif oleh sekolah-sekolah dengan melakukan kegiatan pelatihan dalam mengembangkan kompetensi guru dalam mengoptimalkan pembelajaran daring atau online learning sebagai solusi pembelajaran jarak jauh dengan menggunakan perangkat komputer atau gadget dimana guru dan siswa berkomunikasi secara interaktif dengan memanfaatkan media komunikasi dan informasi.

Kendala ketika pembelajaran daring adalah pola kebiasaan cara belajar mengajar siswa dan yang sudah terbiasa belajar secara konvensional. Guru masih belum terbiasa mengajar dengan memanfaatkan media daring kompleks yang harus dikemas dengan efektif, mudah diakses dan dipahami oleh siswa. Sedangkan siswa sangat membutuhkan budaya belajar mandiri dan kebiasaan untuk belajar mengikuti koputer atau gadget.

Guru dituntut untuk mampu merancang atau mendesaian pembelajaran daring yang ringan dan efektif, dengan memanfaatkan perangkat atau media daring yang tepat dan sesuai dengan materi yang di ajarkan. Sehingga pembelajaran tetap bisa terlaksana dan tetap menerapkan protocol kesehatan secara ketat dan baik sesuai Instruksi Presiden Nomor 6 Tahun 2020 tentang Peningkatan Disiplin dan Penegakan Hukum Protokol Kesehatan Dalam Pencegahan dan Pengendalian Corona Virus Disease 2019.

Pembelajaran daring akan memberikan kesempatan lebih luas dalam mendeskripsikan yang akan diajarkan. Guru harus mampu memilih dan membatasi sejauh mana cakupan materinya dan aplikasi apa yang cocok pada materi dan metode belajar yang digunakan mengingat pengetahuan agama Hindu yang dipelajari para peserta didik menjadi sumber nilai dan penggerak perilaku mereka. Sekadar contoh, di antara nilai budi pekerti dalam agama Hindu dikenal dengan Tri Marga (bakti kepada Tuhan; orang tua, dan guru; karma, bekerja sebaik-baiknya untuk dipersembahkan kepada orang lain dan Tuhan; Jnana, menuntut ilmu sebanyak-banyaknya untuk bekal hidup dan penuntun hidup), dan Tri Warga (dharma, berbuat berdasarkan atas kebenaran; artha, memenuhi harta benda kebutuhan hidup berdasarkan kebenaran, dan kama, memenuhi keinginan sesuai dengan norma norma yang berlaku). Dalam pembentukan budi pekerti, proses pembelajarannya mesti mengantar mereka dani pengetahuan tentang kebaikan, lalu menimbulkan komitmen terhadap kebaikan, dan akhirnya benar benar melakukan kebaikan.

Pembelajaran Daring juga tetap mengutamakan pembudayaan dan pemberdayaan peserta didik sebagai pembelajar sepanjang hayat. Pembelajaran yang menerapkan nilainilai dengan materi keteladanan (ing ngarso sung tulado), membangun kemauan(ing madyo mangun karso dan mengembangkan kreativitas peserta didik dalam proses pembelajaran (tut wuri handayani). 
Pembelajaran yang berlangsung di rumah di sekolah dan di masyarakat. Pembelajaran yang menerapkan prinsip bahwa siapa saja adalah guru, siapa saja adalah peserta didik, dimana saja saja adalah kelas. Pemanfaatan teknologi informasi dan komunikasi untuk meningkatkan efisiensi dan efektivitas pembelajaran. pengakuan atas peredaan indvidual dan latar belakang budaya peserta didik.

Menghadapi tantangan pembelajaran agama Hindu di tengah pandemi Covid 19 dengan strategi pembelajaran yang inovatif merupakan tugas guru yang harus adaktif dengan perubahan, Pembelajaran adalah proses interaksi antarpeserta didik, antara peserta didik dengan pendidik dan sumber belajar pada suatu lingkungan belajar. Berdasarkan Peraturan Pemerintah Nomor 32 Tahun 2013 Pasal 19 menjelaskan bahwa "Proses pembelajaran pada satuan pendidikan diselenggarakan secara interaktif, inspiratif, menyenangkan, menantang, memotivasi peserta didik untuk berpartisipasi aktif, serta memberikan ruang yang cukup bagi prakarsa, kreativitas, dan kemandirian sesuai dengan bakat, minat serta perkembangan psikologis peserta didik".

\section{PEMBAHASAN}

\section{A. Pembelajaran Agama Hindu di Masa Pandemi (Covid 19)}

Mata Pelajaran Agama Hindu dan Budi Pekerti memiliki karakteristik yang berbeda dengan mata pelajaran lainnya. Mengapa? Karena memuat 5 (lima) aspek. Kelima aspek tersebut adalah Aspek Veda, Aspek Tattwa, Aspek Ethika/Susila, Aspek Acara dan Aspek Sejarah Agama Hindu. Dari 5 (lima) aspek Mata Pelajaran Agama Hindu dan Budi Pekerti dapat membangun karakteristik sebagai berikut. 1). Mata Pelajaran Agama Hindu dan Budi Pekerti merupakan pendidikan dalam usaha membentuk kepribadian yang berakhlak mulia, meyakini Sang Hyang sebagai sumber segala yang ada dan yang akan ada. Oleh karena itu, Pendidik Hindu dan Budi Pekerti dijadikan kompas hidup, serta pedoman hidup dan kehidupan (way of life). 2). Mata Pelajaran Agama Hindu dan Budi Pekerti memuat kajian komprehensif bersifat holistik terhadap seluruh proses kehidupan pada dua dimensi tempat skala- niskla atau alam semasih hidup dan alam setelah kematian. Mengemban dan mengisi seluruh proses hidup dan kehidupan di dunia nyata/skala bertumpu pada visi moksartam jagathita ya ca ithi dharma, yaitu sampai pada kehidupan yang sejahtera, teduh, damai dan bahagia. Visi tersebut dijabarkan melalui misi membangun karakter yang penuh sraddha dan bhakti.

Mata Pelajaran Agama Hindu dan Budi Pekerti menggunakan beberapa pendekatan pembelajaran interaktif terpadu yang bersifat demokratis, humanis, fungsional, dan kontekstual sesuai dengan yuga-yuga atau periodisasi masa kehidupan dalam agama Hindu. Pada masa Kali-Yuga dimana periaku kebaikan dharma) persentasenya lebih kecil dibandingkan persentase perilaku negatif (adharma). Oleh karena itu, strategi pembelajaran melalui metode daring terhadap peserta didik di masa pandemi (covid 19) harus dikemas sebaik mungkin agar menjadi pendekatan pembelajaran yang menekankan pada peranan dan fungsi agama sebagai inspirasi hotivasi berperilaku seperti yang ada dalam ranah Kompetensi Inti agar dalam keseharian berprilaku, disiplin, tanggung jawab, santun, peduli dan percaya diri dalam berinteraksi dengan keluarga, teman, pendidik, dan lingkungan.

Pembelajaran Agama Hindu di masa pandemi tetap menekankan Imperensial, yaitu pola pendekatan menjadikan peserta didik secara intens mengembangkan religiusitasnya 
dalam kehidupan sehari-hari dari berpikir berkata dan berbuat. Karena meyakini keberadaan Sang Hyang Widhi disetiap ruang dan waktu, pada akhirnya akan berimplikasi pada perilaku jujur, murah hati rendah hati, kasih yang mendalam dan selalu berkontribusi terhadap kehidupan ini.

Beberapa sekolah bahkan mungkin sudah memiliki dan membangun sistem elearning sendiri. That's good! Setelah mengenal berbagai alternatif platform atau media pembelajaran online, yang tidak kalah penting untuk dipelajari para guru dalam pelaksanaan pembelajaran daring adalah terkait $\mathrm{M}$ berikutnya, metode. Ini terkait bagaimana guru/dosen men-deliver konten secara efektif.

Bagaimana guru bisa menyusun strategi pembelajaran (instructional strategies) daring yang notabene berbeda dengan pembelajaran luring ini secara efektif. Penting diingat bahwa berbagai macam platform itu, mulai dari yang sederhana seperti whatsapp sampai beberapa LMS yang agak kompleks seperti Moodle dan G Suite itu hanyalah media atau alat untuk memfasilitasi pembelajaran. Bukan penentu keberhasilan.

Sementara kualitas hasil pembelajaran etap ditentukan oleh bagaimana guru mendeliver pembelajarannya. Tidak ada hubungan langsung antara kualitas hasil pembelajaran dengan bagus tidaknya platform yang digunakan. Ke depan, sbtelah mengenal berbagai macam media pembelajaran daring, berbagai webinar atau pelatihan yang diadakan perlu memperbanyak pembahasan 'bagaimana, tak lagi sekedar apa:. Guru mesti memperkaya dini dengan berbagai ide kreatif tentang bagaimana membelajarkan siswa secara efektif dengan bertumpu pada jaringan internet dan komunikasi maya.

\section{B. Pembelajaran Agama Hindu Daring dengan 3 M(Media, Metode dan Materi)}

Terkait desain pembelajaran daring, penting bagi guru untuk memastikan adanya interaksi, ada umpan balik, ada komunikasi yang terencana antar siswa dengan guru atau antara satu siswa dengan siswa yang lain selama masa pandemi. Dengan interkasi dan komunikasi yang efektif diharapkan tumbuhnya sense of community diantara siswa dan guru.

Guru juga perlu mendesain aktivitas pembelajaran yang variatif. Tidak hanya bertumpu pada video konferensi yang sinkronous, tetapi juga platform belajar dengan moda asinkkronous. Guru juga perlu mempertimbangkan pemakaian teknologi yang hightech atau lowtech yang nanti akan berakibat pada pemakaian data siswa.

Pada saat yang sama, guru tentu perlu memperkaya $M$ berikutnya, materi atau resources (materi ajar. Guru juga hakbs bergerak dan mengakselerasi kemampuannya untuk mencari atau bahkan membuat materi ajar digital. Setidaknya pandai mendigitalisasi materi yang sebelumnya manual. Pelatihan pembuatan konten digital menjadi juga penting dilakukan. Guru perlu membekali diri mereka dengan skill vide editing, misalnya Termasuk bagaimana menyimpan dan mendesiminasi konten digital mereka melalui berbagai platform yang tak hanya bisa diakses secara terbatas oleh siswa, tetapi juga oleh siswa lain.

\section{Penerapan Pembelajaran Agama Hindu Berbasis Daring}

"Widya Sastra Sudharma Pinaka De Pada Ikanang Tri Buana", artinya Pengetahuan sastra bersumber dari tiga hal utama yang dapat meresapi Alam semesta beserta isinya. Tiga hal utama yang dapat menjadi sumber dari pengetahuan antara lain : Sastratah, Gurutah dan Swahtah. Sastratah merupakan Sumber Pengetahuan menurut refrensi sastra, literatur, kitab, lontar dst. Gurutah sumber dari pengetahuan berpedoman pada guru, yang mana disebut Guru?, selain Tri Kasinanggah Guru tiada lain yakni Seluruh 
Elemen Alam Semesta ini adalah Guru yang Utama (Sarwa Byogatah Guru) bahkan Pengalaman Hidupun merupakan guru utama sering distilahkan "Experience is the best Teacher", kemudian Swahtah ini mengacu pengalaman, pengetahuan didapatkan langsung melalui pengalaman praktek/action.

Tanpa Adanya Praktek setebal apapun buku yang dibaca maupun dihafalkan tidak ada artinya tanpa action konkreat. Pengetahuan hanya ditataran permukaan saja yang dijadikan komoditi Show Up semata, atau hafalan-hafalan saja.

Begitu juga dalam lingkungan pendidikan Hindu yang diikht oleh adanya Unsur Tripitama yakni Tiga Pilar Utama yaitu Tattwa, Susila dan Acara. Ditengah derasnya arus Pandemi Covid-19 ini menerpa Tri Pitama Hadir sebagai Tonggak untuk menggantikan fase peradaabaan manusia dari dulunya "nyengker dewek' atau berdiam diri dirumah saja, sekarang sudah beralih ke fase New Normal, namun kendalanya sangat banyak apabila akan terjadinya New Normal, resikonya sangat besar namun seiring dengan kebiasaan yang dilakukan sesuai dengan Protap kesehatan dan masyarakat disiplin maka akan tercipta New Normal sesuai ekspektasi.

Jika hanya nyaman pada zona yang monoton maka menjadikan generasi ernas ini terkungkung urang kreatif serta inovatif maka peranan keluarga penting untuk merepakan $3 \mathrm{M}$ (Media.Metode, dan Materi) yang inovatif dalam ajaran agama didasarkan pada Darsana yaitu mencari pengthu kebearan degan sudut pandang yang saling berbeda satu dengan lain.

Jadi solusi yang ditawarkan dan bisa dijadikan pertimbangan kembali untuk dipilah terlebih dahulu dan dipilih solusinya sesuai kepentingan di dalam dunia pendidikan antara lain (1) Bangun suasana belajar bersama di dalam keluarga bahwa orang tua mau mendengarkan keluh kesah anak dalam belajar dan diberikan maten ajar dari sekolahnya secara online (2)Tingkatkan Sradha dan bhakti serta mulat sarira didalam Keluarga dan selalu melaksanakan metode HOTS (3 Selalu pergunakan rasa dan rasio serta raga dalam mengambil keputusan dalam bertindakan terhadap kesehatan pribadi yang dimiliki, (4) prioritaskan belajar konkret (nyata) mengenai hidup danipada konsep yang tinggi. (5) Lihatiah peluang kerja dan belajar untuk bisa survive hidup dalam keluarga ditengah wabah covid-19 ini.

\section{PENUTUP}

Mata Peajaran Agama Hindu dan Budi Pekerti menggunakan pembelajaran interaktif terpadu yang bersifat demokratis, humanis, fungsional, dan kontekstual sesuai dengan yuga-yuga atau periodisasi masa kehidupan dalam agama Hindu. Pada masa Kali Yuga dimana perilaku kebaikan (dharma) persentasenya lebih kecil dibandingkan persentase perilaku negatif (adharma). Oleh karena itu, strategi pembelajaran melalui metode Daring terhadap peserta didik di masa pandemi (covid 19) harus dikemas sebaik mungkin agar menjadi pendekatan pembelajaran yang menekankan pada peranan dan fungsi agama sebagai inspirasi dan motivasi berperilaku seperti yang ada dalam ranah Kompetensi Inti agar dalam keseharian berperilaku, disipin, tanggung jawab. santun, peduli. dan percaya diri dalam berinteraksi dengan keluarga, teman, pendidik, dan lingkungan.

Pembelajaran Agama Hindu Daring dengan 3 M (Media, Metode, dan Materi) guru bisa mengenal berbagai alternatit platform atau media pembelajaran menggunakan what'sapp, blog, 200m, webex, google meet, messengger, instagram live, youtube live, $\mathrm{g}$ suite, moodle, edmudo dan disesuaikan dengan metode yang sesuai dengan cakupan 
maten yang diajarkan karena Selain Media dan metode kualitas hasil pembelajaran tetap ditentukan oleh bagaimana guru mendeliver materi pembelajarannya.

Penerapan Pembelajaran Agama Hindu berbasis Daring meliputi (1) membangun suasana belajar bersama di dalam keluarga bahwa orang tua mau mendengarkan keluh kesah anak dalam belajar dan diberikan materi ajar dari sekolahnya secara online (2)Tingkatkan Sradha dan bhakti serta mulat sarira di dalam keluarga dan selalu melaksanakan metode HOTS (3) Selalu pergunakan rasa dan rasio serta dalam mengambil keputusan dalam bertindakan terhadap kesehatan pribadi yang dimilki, (4) prionitaskan belajar konkret (nyata) mengenai hidup daripada konsep yang tinggi, (5) lihatlah peluang kerja dan belajar untuk bisa survive hidup Keluarga ditengah wabah covid-19 ini.

\section{DAFTAR PUSTAKA}

Anggrawan, A. (2019). Analisis Deskripstif Hasil Belajar Pembelajaran Tatap Muka dan Pembelajaran Online Menurut Gaya Belajar. MATRIK: Jurnal Manajemen, Teknik Informatika dan Rekayasa Komputer, 18 (2), 339-346. https://doi.org/10.30812/matrik.v18i2.411.

Anggereini, E. (2017). Asif, A.R., \& Rahmadi, F.A. (2017). Hubungan tingkat kecanduan gadget dengan gangguan emosi dan perilaku remaja usia 11-12 tahun (Doctoral dissertation, Faculty of Medicine). Astuti, P., \& Febrian, F. (2019). Blended Learning Syarah; Bagaimana Penerapan dan Persepsi Mahasiswa. Jurnal, 4 (2), 111-119. https://doi.org/10.31629/jg.v4i2.1560.

Bender L. (2020). Pesan dan Kegiatan Utama Pencegahan dan Pengendalian COVID-19di Sekolah. Publikasi UNICEF.

Budianto, Y. (2020). Memahami Karakter Virus dan Penyakit Covi-19. https://bebas.kompas.id/baca/riset/2020/03/14/memahami-karakter-virus-danpenyakit-korona-Covid-19/. Diakses tanggal 1 Juni 2020.

Coronavirus.jhu.edu. Dashboard by the Center for Systems Science and Engineering (CSSE). https://coronavirus.jhu.edu/map.html. Diakses pada Tanggal 8 Mei 2020.

Covid.kemkes.go.id. Status Harian Covid-19di Indonesia. https://Covid19.kemkes.go.id/situasi-infeksi-emerging/info-corona-virus/. Diakses pada 25 April 2020 -12 Juli 2020.

Naserly, M.K. (2020). Implementasi Zoom, Google Classroom, dan Whatsapp Group Dalam Mendukung Pembelajaran Daring (Online) (Studi Kasus pada 2 Kelas Semester 2, Jurusan Administrasi Bisnis, Fakultas Ekonomi dan Bisnis, Universitas Bina Sa. Aksara Public, 4 (2), 155-165.

Permenkes 9 tahun (2020). Pedoman PSBB dalam rangka Percepatan Penanganan COVID19.

Tim Kerja Kementrian Dalam Negeri untuk Dukungan Gugus Tugas Covid-19. (2020). Pedoman Umum Menghadapi Pandemi Covid-19bagi Pemerinth Daerah Pencegahan, Pengendalian, Diagosis dan Manajemen. Jakarta: Kementrian Dalam Negeri. 